\title{
Histopathological Evaluation of Tumours And Cysts of The Epidermis and Dermal Adnexae in a Tertiary Care Hospital
}

\author{
Ramya Gandhi and Sriram Vijayaraghavan*
}

Department of Pathology, Sri Manakula Vinayagar Medical College and Hospital, Puducherry, India

\section{ABSTRACT}

Background: Skin tumours are a challenging group of conditions, it is difficult to classify and these are diagnosed chiefly by histopathology. The aim of our study was to analyze the incidence and classify the histopathological pattern of tumours and cysts of the epidermis and dermal appendages.

Methods: The current study was a retrospective observational study of epidermal and adnexal tumours and cysts over a period of five and half years from January2007 to December 2012 reported in the department of Pathology ,SMVMCH,Pondicherry over a 5 year period from were analysed and correlated statistically.

Result: Out of 160 skin lesions 62 were found to be epidermal and dermal adnexal tumours, among these benign adnexal tumours(14\%) were the commonest followed by benign epidermal tumours(12.5\%), malignant epidermal tumours(10.5\%) and malignant adnexal tumours(2\%). The ratio of benign(42) to malignant(22) tumour was 1.9:1.the ratio of benign(20) to malignant(17) epidermal tumour was 1.17:1 .The ratio of benign adnexal(22) to malignant counterpart (3) was 7.3:1 and the ratio of skin tumours (62) to cystic lesion(98) was 1:1.5. The commonest epidermal tumour was seborrheic keratosis. Epidermal cysts were the commonest type of cyst in the epidermis. Common skin appendage tumours were nodular hidradenoma followed by pilomatrixoma. The common malignant tumour was basal cell carcinoma.

Conclusion: Cutaneous tumours represent the complexity of the epidermal and dermal adnexae since they have a similar morphology to their cell of origin. Hence the histopathological examination is mandatory for diagnosis and categorization of these tumours

\section{Keywords: Squamous Cell Carcinoma , Basal Cell Carcinoma And Adnexal Tumour}

\section{Introduction}

Skin is a complex organ in which precisely regulated, cellular and molecular interaction govern many crucial responses to our environment and it indicates many internal diseases and cutaneous neoplasia they may be divided into number of categories, reflecting their different biologic behaviours, and decreasing differentiation. These include hamartoma, hyperplasia, cyst, benign tumours , malignant epidermal tumours and appendegeal tumours ,${ }^{[1-3]}$ some of them can be a metastatic deposits of some internal malignancies ${ }^{[4]}$ leading to morbidity and mortality Some of the tumours associated with syndromes like cowdens disease .Clinical diagnosis of different entities is often difficult, because of the identical gross findings and morphological overlap of various epidermal tumours and cystic lesions with many appendegeal tumours .Hence the histopathological examination is mandatory for diagnosis and its pattern analysis . ${ }^{[5-7]}$. The aim of the present study was to observe and analyze the incidence and identify the common type of cutaneous lesions and the variety of histopathological patterns of skin tumours .

\section{Materials and Methods}

It was a descriptive and retrospective (observational) study conducted over a period of five and half years from January 2007 to December 2012 in the Pathology Department of Sri Manakula Vinayagar Medical College and Hospital[SMVMCH], Puducherry . The materials for this study included only the histopathologically diagnosed tumours and cysts of the epidermis, dermal adnexal tumours and cutaneous secondaries. The other tumours and cysts of the genitalia, tumours of the mucous membranes were excluded. The formalin fixed paraffin embedded skin biopsy tissue sections stained with Hematoxylin and eosin slides were retrieved and studied and their patterns were analysed to distinguish each entity. We had totally 160 cases in this study and the tumours were categorized based on the classification of Lever's textbook. Ethical clearance for this study was approved by the institutional ethical committee. The results were expressed in percentage by using a software Statistical Package for Social Science(SPSS), version 16.0.

\section{Result}

The retrospective study of medical records showed that 160 cases of epidermal tumours, dermal adnexal tumours and cystic lesions. Out of these 160 cases, Males were 82 cases $(51.3 \%) \&$ Females were 78 cases $(48.8 \%)$. The male-female ratio was 1.05:1 . Cystic lesions formed the major comoponent of our study consisting of 98 
cases $(61.3 \%)$ with epidermal and dermal adnexal tumours comprising of $37(23.1 \%) \& 25(15.6 \%)$ respectively .In these 62 tumours, $42(26.3 \%)$ were benign and 20(12.5\%) were malignant. Benign tumours was found to be more common among males whereas malignant tumours were found common in females .Although overall skin lesions were more common in males according to our study were shown in Table 1. It was observed that the mean age group of skin lesions ranges from $42.23 \pm 18.33$ the peak incidence of epidermal tumours are $4^{\text {th }}$ to $6^{\text {th }}$ decade and the dermal adnexal tumours and the cystic lesions are more common in $2^{\text {nd }}$ and $4^{\text {th }}$ decade and malignant tumours are in $5^{\text {th }}$ to $7^{\text {th }}$ decade with a significant $P$ value of 0.000 were shown in Table 2. In this present study lesions are more common in trunk, face and extremities with a significant $P$ value of 0.013 .

Out of 160 cases Epidermal tumours constitute $23.1 \%$ of total neoplastic lesions of which 20 were benign, 17 were malignant, 98(61.3\%) were tumor like cystic lesions. Among the tumor like cystic lesions commonest was Epidermal cyst which occured more often in face, next common was dermoid cyst followed by Trichilemmal cyst, which was commonly seen in scalp with a significant $\mathrm{P}$ value of 0.00 were shown in Table 3 . .
In this present study benign tumours accounted for $42(26 \%)$ out of 160 cases in that Seborrheic keratosis 17(41\%) were found to more common followed by keratoacanthoma $2(5 \%)$ in epidermal tumor followed by tumour with eccrine differentiation (6.8\%) were common. Among the malignant tumours basal cell carcinoma(40\%) was the commonest tumour according to our study followed by squamous cell carcinoma(35\%) and then malignant adnexal tumours $(15 \%)$. Apart from that two cases of cutaneous metastasis were observed in this study were shown in Table $4 \& 5$ respectively.

Appendageal tumours encountered were 25( $15.6 \%$ ) of the study group, $22(13.8 \%)$ of them were benign and $3(1.8 \%)$ were malignant. The tumours derived from eccrine were $11(6.8 \%)$ cases ,apocrine were $2(1.3 \%)$, follicular were $7(4.4 \%)$ and sebaceous differentiation were $2(1.3 \%)$.The maximum occurance of adnexal tumour was at extremities $10(6 \%)$ followed by face $6(4 \%)$ and trunk $6(4 \%)$. Most of them occurred as nodules and papules. Tumours of follicular differentiation were more often seen in scalp and face. There were 10 males and 15 females, aged 8 years to 80 years, (median -36 years). Out of these 25 cases nodular hidradenoma and pilomatricoma was the two most common benign skin adnexal tumours in the current study Table 6.

Table 1: Sex Distribution of Tumours and Cysts.

\begin{tabular}{|c|c|c|c|c|}
\hline Sex & Epidermal tumour & Adnexal tumour & Cystic lesions & $\%$ \\
\hline Female & $15(9.4 \%)$ & $15(9.4 \%)$ & $48(30.0 \%)$ & $78(48.8 \%)$ \\
\hline Male & $22(13.7 \%)$ & $10(6.3 \%)$ & $50(31.3 \%)$ & $82(51.3 \%)$ \\
\hline \multicolumn{5}{|c|}{ SEX DISTRIBUTION IN BENIGN AND MALIGNANT TUMOURS OF SKIN } \\
\hline NATURE & MALE & FEMALE & TOTAL & PERCENTAGE \\
\hline \multicolumn{5}{|c|}{ EPIDERMAL TUMOUR } \\
\hline Benign & 10 & 12 & 22 & 36 \\
\hline Malignant & -- & 3 & 3 & 5 \\
\hline \multicolumn{5}{|c|}{ ADNEXAL TUMOUR } \\
\hline Benign & 14 & 6 & 20 & 32 \\
\hline Malignant & 8 & 9 & 17 & 27 \\
\hline TOTAL & $32(52 \%)$ & $30(48 \%)$ & 62 & 100 \\
\hline
\end{tabular}

Table 2: Age Distribution.

\begin{tabular}{|c|c|c|c|c|c|c|}
\hline \multirow{2}{*}{ Age } & \multicolumn{2}{|c|}{ Epidermal tumours } & \multicolumn{2}{|c|}{ Adnexal tumours } & \multirow{2}{*}{ Cystic lesions } & \multirow{2}{*}{$\begin{array}{c}\text { Total } \\
\%\end{array}$} \\
\hline & Benign & Malignant & Benign & Malignant & & \\
\hline $0-20$ & --- & -- & $3(1.8 \%)$ & -- & $21(13.0 \%)$ & $14.8 \%$ \\
\hline $21-40$ & $4(2.5 \%)$ & -- & $11(6.8 \%)$ & -- & $40(25.0 \%)$ & $34.3 \%$ \\
\hline $41-60$ & $8(5.0 \%)$ & $10(6.3 \%)$ & $6(3.8 \%)$ & $1(0.6 \%)$ & $30(19.0 \%)$ & $34.5 \%$ \\
\hline $61-80$ & $8(5.0 \%)$ & $7(4.4 \%)$ & $2(1.3 \%)$ & $2(1.3 \%)$ & $7(4.3 \%)$ & $16.3 \%$ \\
\hline TOTAL & \multicolumn{2}{|c|}{$37(23.1 \%)$} & \multicolumn{2}{|c|}{$25(15.6 \%)$} & $98(61.3 \%)$ & 100.0 \\
\hline
\end{tabular}

Mean $\pm S D: 42.23 \pm$ 18.33. Chi square $=33.22, P$ value $=0.000$ [Significant] 
Table 3: Epidermal Tumours and Cysts.

\begin{tabular}{|c|c|c|}
\hline LESIONS & Number of cases & Percentage \\
\hline \multicolumn{2}{|c|}{ Benign tumours } \\
\hline Seborrhoeic keratoses & 17 & $10.6 \%$ \\
\hline Keratoacanthoma & 2 & $1.0 \%$ \\
\hline Warty dyskeratoma & 1 & $4.3 \%$ \\
\hline Squamous cell carcinoma & Malignant tumours & $5.0 \%$ \\
\hline Basal cell carcinoma & 7 & $1.25 \%$ \\
\hline Cutaneous metastasis & 8 & \\
\hline & 2 & $36.3 \%$ \\
\hline Epidermal cyst & Cystic lesions & $12.5 \%$ \\
\hline Dermoid cyst & 58 & $10.6 \%$ \\
\hline Trichilemmal cyst & 20 & $1.0 \%$ \\
\hline Steatocystoma multiplex & 17 & $1.25 \%$ \\
\hline Eruptive vellus hair cyst & 1 & \\
\hline
\end{tabular}

The chi-square value is 76.0766 and the p value is 0.00 (significant)

Table 4: Distribution of Benign Tumours of Skin.

\begin{tabular}{|c|c|c|}
\hline TUMOURS & NUMBER OF CASES & PERCENTAGE \\
\hline EPIDERMAL & 20 & 48 \\
\hline Seborrheic keratosis & 17 & 5 \\
\hline Keratoacanthoma & 2 & 2 \\
\hline Warty dyskeratoma & 1 & 52 \\
\hline ADNEXAL & 22 & 26 \\
\hline Tumours With Eccrine Differentiation & 11 & 5 \\
\hline Tumours With Apocrine Differentiation & 2 & 16 \\
\hline Tumours With Hair Follicle Differentiation & 7 & 5 \\
\hline Tumours With Sebaceous Differentiation & 2 & 100 \\
\hline Total number of cases & $\mathbf{4 2}$ & \\
\hline
\end{tabular}

Table 5: Distribution of Malignant Tumours of Skin.

\begin{tabular}{|c|c|c|}
\hline TUMOURS & NUMBER OF CASES & PERCENTAGE \\
\hline EPIDERMAL & 17 & 35 \\
\hline Squamous cell carcinoma & 7 & 40 \\
\hline Basal cell carcinoma & 8 & 10 \\
\hline Cutaneous metastasis & 2 & 15 \\
\hline ADNEXAL & 3 & 5 \\
\hline Malignant eccrine spiradenoma & 1 & 5 \\
\hline Porocarcinoma & 1 & 5 \\
\hline Malignant adnexal tumour unclassifiable & 1 & 100 \\
\hline TOTAL & $\mathbf{2 0}$ & \\
\hline
\end{tabular}


Table 6: Distribution of Adnexal Tumours.

\begin{tabular}{|c|c|c|}
\hline Adnexal tumours & Number of cases & Percentage \\
\hline Benign tumours with eccrine Differentiation & 11 & 44 \\
\hline Nodular hidradenoma & 7 & $28 \%$ \\
\hline Eccrine poroma & 1 & $4 \%$ \\
\hline Syringoma & 2 & $8 \%$ \\
\hline Chondroid syringoma & 1 & $4 \%$ \\
\hline Malignant tumours with eccrine differentiation & 3 & 12 \\
\hline Eccrine porocarcinoma & 1 & $4 \%$ \\
\hline Malignant eccrine spiradenoma & 1 & $4 \%$ \\
\hline Malignant adnexal tumour & 1 & $4 \%$ \\
\hline Apocrine Differentiation & 2 & 8 \\
\hline Apocrine hidrocystoma & 1 & $4 \%$ \\
\hline Syringocystadenoma pappiliferrum & 1 & $4 \%$ \\
\hline Follicular Differentiation & 7 & 28 \\
\hline Pilomatricoma & 4 & $16 \%$ \\
\hline Trichoepithelioma & 1 & $4 \%$ \\
\hline Trichoadenoma & 1 & $4 \%$ \\
\hline Proliferating trichilemmal tumour & 1 & $4 \%$ \\
\hline Sebaceous differentiation & 2 & 8 \\
\hline Nevus sebaceous & 2 & $8 \%$ \\
\hline TOTAL & 25 & 100 \\
\hline
\end{tabular}

Table 7: Comparison of Skin Lesions Between Other Studies.

\begin{tabular}{|c|c|c|c|}
\hline & De silva et al[4] & Qiu JH Zhonghua Zhong et al [10] & Present study \\
\hline Total no.of cases & 1181 & 32425 & 160 \\
\hline Benign tumours & $1024(86.4 \%)$ & $2137(62.4 \%)$ & $42(26.3 \%)$ \\
\hline Malignant tumours & $157(13.3 \%)$ & $1288(37.68 \%)$ & $20(12.5 \%)$ \\
\hline Benign epidermal tumours and cysts & $915(89.35 \%)$ & $1742(81.5 \%)$ & $140(87.5 \%)$ \\
\hline \multicolumn{4}{|c|}{ Distribution of individual tumor groups: } \\
\hline Benign adnexal tumours & $83(7.03 \%)$ & $395(18.5 \%)$ & $22(52.38 \%)$ \\
\hline Malignant epidermal tumours & $157(13.3 \%)$ & $1254(97.3 \%)$ & $17(85 \%)$ \\
\hline SCC & $96(61.1 \%)$ & $958(74.4 \%)$ & $7(35.0 \%)$ \\
\hline $\mathrm{BCC}$ & $61(38.8 \%)$ & $296(23.0 \%)$ & $8(40.0 \%)$ \\
\hline SCC:BCC & $1: 1.5$ & $3.2: 1$ & $1: 1.4$ \\
\hline Malignant adnexal tumours & -- & $34(2.6 \%)$ & $3(15.0 \%)$ \\
\hline Site & --- & Head\&neck & Trunk\&Face \\
\hline Sex & $1: 1$ & $1.5: 1$ & $1.1: 1$ \\
\hline
\end{tabular}


Table 8: Comparison of Adnexal Tumours.

\begin{tabular}{|c|c|c|c|c|c|}
\hline & $\begin{array}{c}\text { Yaqoob N } \\
\text { et al }{ }^{[19]}\end{array}$ & Nair $P$ et al[20] & $\begin{array}{l}\text { Samaila MO } \\
\text { et al }\end{array}$ & $\begin{array}{l}\text { Solanki AL } \\
\text { et al }{ }^{[22]}\end{array}$ & $\begin{array}{l}\text { Present } \\
\text { study }\end{array}$ \\
\hline Total no of cases & 166 & 33 & 52 & 94 & 25 \\
\hline Period of study & 4 year & 3 year & 16 year & 27 year & 5 year \\
\hline $\begin{array}{l}\text { Sweat gland } \\
\text { tumour(eccrine\&apocrine) }\end{array}$ & $86(51.8 \%)$ & $19(57.5 \%)$ & $41(78.8 \%)$ & $50(53.2 \%)$ & $16(64.0 \%)$ \\
\hline Hair follicle tumour & $64(38.5 \%)$ & $12(36.36 \%)$ & $4(7.7 \%)$ & $22(23.45 \%)$ & $7(28.0 \%)$ \\
\hline Sebaceous gland tumour & $5(3.0 \%)$ & $2(6.06 \%)$ & $7(13.5 \%)$ & $22(23.4 \%)$ & $2(8.0 \%)$ \\
\hline Mean age & 41 years & 9 years & 33 years & 30years & 42 years \\
\hline$M: F$ & $1: 1$ & $1: 2.3$ & $1: 1$ & $1: 1$ & $1: 1.5$ \\
\hline Common benign tumour & $\begin{array}{c}\text { Nodular } \\
\text { hidradenoma } \\
(41.16 \%)\end{array}$ & $\begin{array}{c}\text { Syringoma } \\
(42.42 \%)\end{array}$ & $\begin{array}{c}\text { Eccrine } \\
\text { acrospiroma } \\
(32.7 \%)\end{array}$ & $\begin{array}{c}\text { Eccrine } \\
\text { acrospiroma } \\
(48.14 \%)\end{array}$ & $\begin{array}{c}\text { Nodular } \\
\text { hidradenoma } \\
(28.0 \%)\end{array}$ \\
\hline
\end{tabular}

\section{Discussion}

Many occasions clinicians are challenged by difficult diagnostic problem where skin biopsy becomes mandatory and facilitates the easy clinical diagnosis and treatment. Several study quoted that histopathological confirmation is the standard tool for evaluating patterns of skin diseases with correct diagnosis .

In this present study Lever ${ }^{[8]}$ classification of cysts , epidermal tumours and dermal adnexal tumours was followed

During the 5 year study period, there was a total of 160 cases. Out of 160 skin lesions 62 were found to be epidermal and dermal adnexal tumours, among these benign adnexal tumours $(14 \%)$ were the commonest tumours followed by benign epidermal tumours(12.5\%), malignant epidermal tumours $(10.5 \%)$ and malignant adnexal tumours( $2 \%)$. The ratio of benign(42) to malignant(22) tumour was $1: 2.1$. The ratio of benign(20) to malignant(17) epidermal tumour was $1.17: 1$.The ratio of benign adnexal(22) to malignant counterpart (3) was 7.3:1 and the ratio of skin tumours (62) to cystic lesions (98) was 1:1.5.

In India skin malignancies are less than $1 \%$ of all cancers compared to western countries. Various reports from India show wide variations in the incidence and types of skin tumours from different parts of the country ${ }^{[9]}$.

From this observation it is confirmed that epidermal tumours(23.1\% )and cystic (tumour like) lesions(61.3\%) are more common than adnexal tumours $(15.6 \%)$ in the present study. And it is compared with the other similar studies were shown in Table 7.
The present study showed slight predilection for males compared to females, the M:R ratio is 1.1:1 it was similar with the study done by Reizner et al (3.16:1),[1]] \&Tan SH et al $(1.4: 1){ }^{[12]}$.

Some studies have shown a marked predilection for female Chaung TY et al, ${ }^{[13]}$.

In the present study that most of the patients were in the age group of 40-80 years and it is agin concordance with the Reizner GT et al, ${ }^{[11]}$ and Tan SH et al, ${ }^{[12]}$ and they found the occurrence of malignant tumour in fourth, sixth and eighth decades of life.

Benign cases in the present study were $26.3 \%$ and the malignant cases were $12.5 \%$. This findings were comparable with Sabir et al, ${ }^{[3]}$.However Kapoor et al found more frequency of malignant cases.

In the study conducted by Chandrasekaran $\mathrm{V}$ et $\mathrm{al},{ }^{[14]}$ observed that cystic lesions were predominent123 and male to female ratio was 2:1 9 it was similar to our present study. Chiu MY et al, ${ }^{[15]}$ reported a case of squamous cell carcinoma arising from an epidermal cyst.

In this present study the maximum number of cases encountered were basal cell carcinoma[BCC] $40 \%$ and it was contrasting from the observations of Deo SV et al, ${ }^{[16]}$ and Chakravarthy $\mathrm{RC}$ et al, ${ }^{[9]}$ followed by $\mathrm{SCC}(35 \%)$ and adnexal tumour(15.6\%). Diepgen TL et al, ${ }^{[17]}$ in 2002 conducted a population based study in Australia and concluded that $\mathrm{BCC}(2 \%)$ is more common than $\mathrm{SCC}(1 \%)$ and is concurrent with our study.

Tumours of skin appendeges: Adnexal tumours (ATs) are relatively rare and the overall incidence of adnexal tumours 
were $15.6 \%$ and this was more than the observation of $12.8 \%$ cases documented by Sanjay N et al, ${ }^{[18]}$. Our study over a period of five and half year shows the rarity and indicates that these tumours are relatively uncommon Importance of diagnosing ATs are in some instances the presence of ATs may lead to the recognition of a genetic syndrome ,like Muir-torre syndrome associated with sebaceous tumours ,Cowdens syndrome with trichilemmomas . ${ }^{[7]}$

In this present study we observed sweat gland tumour was the most common tumour (64.0\%) followed by hair follicle tumour $(28.0 \%)$ and it is concurrent with the studies conducted by Yaqoob et al ${ }^{[19]}$,Nair et a ${ }^{[20]}$, Samila et a ${ }^{[21]}$ Solanki AL et al, ${ }^{[22]}$ its comparison with other studies were shown in Table 8.

Metastatic skin disease: In the present study we observed two cases of cutaneous metastatic deposits of adenocarcinoma of stomach and the infiltrating ductal carcinoma of breast respectively. It was accounting for $10 \%$ of the skin cancer. Histopathologically it showed highly pleomorphic cells with hyperchromatic nuclei and prominent nucleoli.It was concurrent with the study done by Yoskavitch A et al, ${ }^{[7]}$.

\section{Conclusion}

Skin tumours are a challenging group of conditions that can mimic other disorders .Many at times it can be an important clue for a genetic syndrome requiring appropriate management, like sebaceous tumours in MuirTorre syndrome, trichoepithelioma,, basal cell carcinoma in Cowden syndrome. They may also be a marker for internal malignancy such as 'Sign of Leser Trelat' with multiple seborrheic keratosis representing underlying visceral malignancy . Most of the times these skin lesions and tumours will pose a diagnostic difficulties clinically. Hence histopathological evaluation is mandatory for diagnosis and it is useful for determining the treatment and prognosis and also to diagnose the associated familial syndromes.

\section{Acknowledgements}

We are thankful to Dr. Sowmya, Professor of Pathology for her kind guidance. We owe our gratitude to authors, editors and publishers of all those journals from where the literature for our article has been discussed.

\section{Reference}

1. Shilpa V, Mandakini T. Histopathological Study of Tumours of Epidermis and Epidermal Appendages . Indian Journal of Pathology: Research and Practice Volume 6 Number 2, April - June 2017
2. Klein W, Chan E, Seykora JT. Tumours of the epidermal appendages. In: Elder DE, Murphy G. Lever's histopathology of the skin. 9th ed. Philadelphia. 2005; 867- 926.

3. Sabir F,Aziz M.Clinical and cyto-histopathological evaluation of skin lesions with special reference to bullous lesions in Indian journal of pathology and microbiology53(1),January-march2010.

4. DeSilva M, Constantine R ,Amarasekara LR. Cutaneous tumours \& tumourlike Conditions and cysts in sri lankans. The Sri Lanka J Dermatol 1999/2004; 21 -27.

5. Kapoor R, Goswami KC. Pattern of cancer in Jammu region (Hospital based study 1978- 89). Ind J Cancer 1993; 30:67-71.

6. Shivanand G, Rutuja K. Histopathological Study of Skin Tumours. International Journal of Healthcare Sciences. Vol. 2, Issue 2, pp: (155-163), Month: October 2014 - March 2015 .

7. Yoskovitch A, Hier MP, Okrainec A, Black MJ, Rochon L. Skin metastases in squamous cell carcinoma of the head and neck. Department of Otolaryngology- Head and Neck Surgery, McGill University, Montreal, Quebec, Canada. Otolaryngol, Head Neck Surg. 2001 Mar;124(3):248-52.

8. Kirkham N. Tumours and cysts of epidermis. In Lever's histopathology of skin. 10th ed. Philadelphia: Lippincott Raven; 2005. p 805-866.

9. Charkravorthy RC and Choudhuri DR. Malignant neoplasms of the skin in Eastern India. The Indian Journal of Cancer, vol 5,1968:133-144.

10. Qiu JH. Pathological studies on epidermic and appendage tumors and tumor- like lesions analysis of 3,425 cases, Zhonghua Zhong Liu Za Zhi.1986 Jan;8(1):48 .

11. Reizner GT, Chuang TY, Elpern DJ, Stone JL, Evan RF. Basal cell carcinoma in Kauai, Hawaii: The highest documented incidence in the United States. J Am Acad Dermatol 1993;29:184-9.

12. Tan SH, Tham SN, Goh CL. Skin cancers at tertiary referral skin hospital in Singapore. Int J Dermatol 1995;34:770-6.

13. Chuang TY, Popescu A, Chute CG. Basal cell carcinoma: a population Based incidence study in Rochester, Minnesota. J Am Acad Dermatol 1990;22(3):413-7.

14. Chandrashekaran CV, Raghuveer CV ,Prakash S. Epidermal cysts - a clinicopathological and biochemical study. Postgradutate Medical Journal. 1980; 56: 823-827.

15. Chiu MY.Squamous cell carcinoma arising from an epidermal Cyst, Department of Orthopaedics and Traumatology, Caritas Medical Centre, Hong Kong Med J. 2007;13:482-4.

16. Deo SV. Surgical management of skin cancers: Experience from a regional cancer centre in North India. Indian Journal of Cancer 2005; 42:145-50.

17. Diepgen TL, Mahler V. The epidemiology of ski cancer. Br Dermatol. 2002 Apr;146 :Suppl 61:1-6.

18. Sanjay N, Rishi B :Adnexal tumours of skin,Ind J dermatol.43(2)1998. 
19. Yaqoob N Z. Ahmad S. Muzaffar, Gill MS.Spectrum of Cutaneous Appendage Tumors at Aga Khan University Hospital. Journal of Pakistan Medical Association. Vol 53, No.9,Sep 2003.

20. Nair P. A clinicopathologic study of skin appendageal tumors. Indian journal of Dermatology,Venereology ;2008:550.
21. Samaila MOA. Adnexal Skin Tumors In Zaria, Nigeria Annals of African Medicine. Vol 7, No.1; 2008: 6-10.

22. Solanki A L, Anand V K, Gupta K. Neoplasms of Sweat Glands; Indian J Derematol Venereal 1989; 55: 108113.

*Corresponding author:

Sriram Vijayaraghavan, Sri Manakula Vinyagar Medical College and Hospital, Kalitheerthalkuppam, Madagadipet, Puducherry, 605107, India Phone: +91 9787740891

Email: sriram11988@gmail.com

Financial or other Competing Interests: None. 